Article

\title{
Scheduling and Planning in Service Systems with Goal Programming: Literature Review
}

\author{
Şeyda Gür and Tamer Eren * \\ Department of Industrial Engineering, Faculty of Engineering, Kirikkale University, 71450 Kirikkale, Turkey; \\ seydaaa.gur@gmail.com \\ * Correspondence: tamereren@gmail.com; Tel.: +90-318-3574242
}

Received: 1 November 2018; Accepted: 14 November 2018; Published: 19 November 2018

\begin{abstract}
Background: People want to be able to evaluate different kinds of information in a good way. There are various methods that they develop in such situations. Among the optimization methods, the goal programming method is often used when there are multiple objectives that decision makers want to accomplish. Because scheduling and planning problems have multiple objectives that are desired to be achieved, the goal programming method helps the researcher in contradictory situations between these goals. Methods: This study includes, examines, and analyzes recent research on service scheduling and planning. In the literature, service scheduling and planning studies have been examined using goal programming method from past to today. Results: The studies are detailed according to the type of goal programming, according to scheduling types, the purpose used in the studies, and the methods integrated with the goal programming. There are 142 studies in Emerald, Science Direct, Jstor, Springer, Taylor and Francis, Google Scholar, etc. databases that are examined in detail. For readers, diversification has been made to facilitate the identification of these studies and a detailed overview has been presented. Conclusion: As a result of the study, studies with the goal programming in the literature have been seen. The readers' perspectives for planning and scheduling are discussed.
\end{abstract}

Keywords: goal programming; scheduling and planning; service system

\section{Introduction}

Even at any time in everyday life, people may be faced with situations that need to be decided. Deciding is to choose the most appropriate option among many. Optimal results may not always be obtained when a comparison is made between options. Some of the aims may conflict with each other, while others may be proportional to each other. However, too many factors may need to be ignored in order to achieve an optimal solution. Multi-criteria decision making is the decision-making tool to choose the best option among multiple criteria. One of the multi-criteria decision-making methods, the goal programming method, is a method that helps decision-makers when more than one criterion is concerned. By trying to reduce complexity problems, it is tried to reach the determined aims as much as possible. The goal programming method, which is an extension of linear programming, is a commonly used method in the literature. The difference of the goal programming method from the linear programming is to consider many objectives at the same time [1].

There are many purposes in production and service systems that are required to be realized, and there are many factors that affect these goals. In production systems, it is planned in what order and when to do jobs on machines. In service systems, this definition of planning differs and varies for each sector. Each task defined in production systems represents activities that transform a piece and add value to it. In service systems, this activity generally involves people. So, the resources needed can take many different forms and basically all serve humanity. In the service systems, these resources are varied in the health environment such as operating rooms, polyclinics, surgeons and else in 
the transportation such as airline, ship, train, passenger, pilot, or general reservation, course-exam programs. In this system, where there are so many varieties, scheduling and planning are very important. There are many factors that affect scheduling and planning activities. Taking these factors into account, synchronizing the use of different resource types is very difficult in real life. For decision makers, multi-criteria decision-making methods that can take into account multiple objectives that are influenced by various factors are at the forefront. Among these methods, the goal programming method, which is frequently used in the literature and has a high efficiency in order to reach the desired results, is an effective tool. As an extension of linear programming, the goal programming method allows flexibility in performing many purposes in planning and scheduling studies. Therefore, it is mostly preferred by the researchers in the literature. The researchers provide solutions for each scheduling and planning activities in the service sector by using the goal programming method using different performance criteria [2].

When literature studies related to goal programming method are examined; Tamiz et al. [3] examined the literature on two types of goal programming methods. They analyzed the application areas of these 70 studies. Tamiz et al. [4] presented a detailed analysis of the literature on the goal programming method. They emphasized to application areas in order to guide future work by looking from a general point of view. Jones et al. [5] presented a review of 280 studies on goal programming over a period of ten years. By determining the goal programming method as a keyword, they analyzed the application areas of the studies within the ten-year period. Azmi et al. [6] focused on portfolio selection and examined the work done with goal programming in this respect. They talked about the factors that affect portfolio selection in their studies and they included applications that can be worked on for readers. Colapinto et al. [7] focused on a topic rather than examining the goal programming method from a general point of view like other studies. In financial portfolio management, they have examined applications related to goal programming. They have categorized countries, years and so on, and talked about the importance of the subject and its relation to goal programming.

This study intends to examine in detail the studies related to scheduling and planning with goal programming method in service systems. This is the first study to analyze the scheduling and planning studies of the goal programming method which is frequently preferred by the researchers in the literature according to our studies. In addition, unlike other studies in the literature, we have classified the studies according to scheduling and planning types. We have believed that the contributions obtained as a result of the examinations made may be useful for readers who wish to conduct research in these areas. By putting together, the extensive literature covered in detail, the studies have been reflected the extent that readers can understand. Goal programming, scheduling, and planning keywords in Emerald, Science Direct, Jstor, Springer, Taylor and Francis, and Google Scholar databases are scanned while the literature is being searched. The results of the review of 142 studies are compiled.

All of the studies include all the studies that can be achieved as much as the day-to-day study of the first year of the goal programming method being used in the literature. Although the number of studies in the years that the first definition of the goal programming method was made is very small, the number of studies done in recent years has increased [5]. The majority of the studies examined is varied after 2000. With the development of technology and the changing needs of people, planning, and scheduling activities in service systems have also been shaped and differentiated according to needs. Especially in the last decade, these activities have increased and are expected to become even more diverse.

The review structure of this study is basically based on the combination of scheduling and planning activities of the goal programs. This work, which is more specifically structured to allow readers to easily access the information they seek, is divided into 5 sections. Section 2 provides information on which scheduling and planning activities the goal programming method is used for. In Section 3, the types of goal programming that are frequently used in the literature are given. The mathematical formulations of these methods are given to give technical information to the reader. In Section 4, it is mentioned what methods are integrated with the goal programming method in the literature. In Section 5 the information obtained in the investigation is interpreted. 


\section{Goal Programming According to Types of Scheduling and Planning Activities}

Planning and scheduling is an effective tool for decision making in production and service systems. The mechanism to control the sequence of tasks to be performed manually or automatically can be defined as scheduling [2]. Scheduling and planning studies are carried out according to the determined goals and constraints in order to balance the load in a system and ensure that the existing resources are distributed evenly. Mathematical or heuristic methods are used to allocate these jobs to limited resources. This balanced distribution of resources enables businesses to optimize their objectives and reach their goals. Scheduling and planning activities differ in terms of process and service processes, although they are defined as an alignment of tasks and balance of resources. Scheduling and scheduling activities in manufacturing systems are specified as machining or hand-machining in a specific sequence of orders that will be driven to the market in a business environment. Works can be delayed when machines are busy, when machine breakdowns occur, when processing times are longer than planned, when capacities are inadequate. In such cases, detailed scheduling of the tasks or tasks planned to be done helps to increase the efficiency of the processes and ensure continuous control. In manufacturing systems, it is aimed to optimize the allocation of resources based on stock levels, demands, and resource requirements [8].

In scheduling and planning activities in service systems, there are many different problems. Though basically the same as the planning and scheduling function in the manufacturing environment, detailed information systems and decision-making functions are included in service systems. Differences between manufacturing systems and service systems also affect scheduling and planning activities. While the number of resources is kept constant in the production process of a job in manufacturing systems, the number of resources in service systems can change with time. Such variability affects the objective function. For this reason, planning and scheduling activities in service systems are related to capacity management and productivity management [2]. Scheduling and planning activities in service systems have many field applications. It is applied in many different subjects such as manpower scheduling, reservation scheduling, nurse scheduling, personnel scheduling, shift scheduling, transportation systems scheduling, and course scheduling. The goal programming method in the literature has been used in a wide variety of fields in service systems. Table 1 shows the applications in the service sector where researchers use the goal programming method.

Table 1. Studies by scheduling and planning types.

\begin{tabular}{lr}
\hline Course scheduling & {$[9-11]$} \\
\hline Financial planning & {$[12,13]$} \\
\hline Tour scheduling & {$[14-16]$} \\
\hline Shift scheduling & {$[17-22]$} \\
\hline Menu planning & {$[23,24]$} \\
\hline Manpower planning & {$[25-30]$} \\
\hline Maintenance scheduling & {$[31,32]$} \\
\hline Urban planning & {$[33-38]$} \\
\hline Other & {$[39-55]$} \\
\hline Personnel & \\
Nurse scheduling & {$[56-74]$} \\
Staff scheduling & {$[75-87]$} \\
Examiner scheduling & {$[88,89]$} \\
\hline Advertisement & \\
Media planning & {$[90-92]$} \\
Advertisement planning & {$[93]$} \\
\hline
\end{tabular}


Table 1. Cont.

\begin{tabular}{lr}
\hline Agriculture & \\
Agriculture planning & {$[94-96]$} \\
Harvest planning & {$[97-101]$} \\
Land planning & {$[102-105]$} \\
Forest planning & {$[106-108]$} \\
\hline Transportation & \\
Transportation planning & {$[109-112]$} \\
Passenger scheduling & {$[113]$} \\
\hline Waste & {$[114]$} \\
Waste planning & {$[115]$} \\
Solid waste management planning & \\
\hline Healthcare & {$[116-120]$} \\
Master Surgical Scheduling & {$[121]$} \\
Health planning & {$[123-130]$} \\
\hline Polyclinic schedules
\end{tabular}

As shown in Table 1, scheduling and planning activities in service systems vary widely in the literature. With this diversity being too much, the work that a particular inland destination programming method is used to is limited. Nurse scheduling and staff scheduling studies under the heading of personnel appear to be frequently addressed in the literature. Increasing the quality of service provided to customers in service systems is a priority goal. It is also important to increase staff satisfaction in order to provide this service quality at the top level. Taking into consideration the preferences of the staff in working conditions and creating the schedules according to this, causes performance increases. Louly et al. [76], who draw attention to this point and improves productivity with the program they have created, has developed a mathematical model with goal programming. They aimed to create an optimized cyclic program by combining the staff preferences and operating constraints. The flexibility of the goal programming method is an alternative tool for many constraint and objective problems. In a set of work models, soft constraints provide the convenience of developing solutions to these goals and boundaries. At the same time, the excess of the work load on the staff, the staff can tire and reduce the motivation to work. Therefore, the retirement of the staff must be distributed equally. The equal division of staff effort means that the work load of all the staff is balanced. Todovic et al. [79] have developed a methodology to be able to allocate this workload in a balanced way.

In the nurse scheduling problem, which is another type of personnel scheduling, basically, the same goals are sought. Providing patient satisfaction at the top level in health care units is linked to ensuring a high level of employee satisfaction. Careful and productive work by healthcare professionals has vital preventive measures. However, it is seen that there is motivation and loss of performance on the staff through wrong and unfair schedules. Azaiez et al. [56-58] developed a mathematical model for fairness of these schedules and plans by addressing the nurse scheduling problem.

In Table 1, very different application areas are covered by the researchers. While some areas have become the focus of researchers' interest, some studies have remained limited in the literature. In the studies under the other title; the authors of [40] in the planning of information resources for strategic planning in health systems, the authors of [43] in strategic planning for human resources in health systems, the authors of [44] in a basketball league game schedule, the authors of [47] for pre-scheduling in wind power, and the authors of [55] in mine planning used goal programming. When we look at the studies, it is pointed out that real life problems contain too many limitations. It seems that it is very difficult to transfer all of these constraints to mathematical models. At this point, the goal programming method that will soften most constraints, which will help most situations, is at the forefront. Many objectives can be achieved by allowing deviations from these constraints with the goal programming method. In the future, researchers should focus on the work in the areas that 
need to use the goal programming method. They should develop alternative approaches to real-life problems by replicating the limited applications of existing studies.

\section{Goal Programming Types}

There are many purposes to be realized in the problems encountered in everyday life. These aims can be contradictory to each other as well as in the same direction. In such cases, researchers resort to multi-criteria programming methods in order to achieve the objectives simultaneously. One of these methods, Goal Programming, was first described by Charnes et al. [131] in 1961. Decision makers have a hard time developing complex mathematical approaches when there are conflicts of interest or lack of knowledge in complex situations. To reach the desired values for each goal, it is necessary to extend the mathematical approaches to include multiple objectives. In such decision problems, decision makers want to achieve their goals as much as possible. All these concerns place the goal programming method within the multi-criteria programming paradigm [132,133]. There are three different goal programming methods used by researchers in the literature. Although Lexicographic Goal Programming and Weighted Goal Programming are frequently used, Chevyshev Goal Programming, also known as Minmax Goal Programming, is another less commonly used method.

Extensions of the goal programming method include extended goal programming, interval goal programming, lexicographic extended goal programming, and lexicographic Minmax goal programming methods (minimize the maximum deviation between goals). The extended goal programming method is used when decision makers wish to consider the number of goals reached. Researchers benefit from the flexibility of the expanded goal programming method to bring together the philosophies underlying the problems. They talk about the ability to produce solutions that fully reflect the basic criteria of the problems [134]. Another variant of this method is the lexicographic extended goal programming method [135]. Interval goal programming method minimizes the weighted sum of unwanted deviation variables within a given set of ranges [136]. The lexicographic Minmax goal programming method (minimize the maximum deviation between goals) represents the preferences of researchers more accurately in certain situations [137].

Researchers use these methods when the classical goal programming approach is not sufficient. In the multi-choice goal programming method developed in cases where the current goal formulation is not solved, multi-choice aspiration situations are taken into consideration. These multi-choice aspiration levels may be present in decision-making. It allows decision makers to determine multi aspiration levels for yield "higher/better" and "less/better" problems at aspiration levels [138]. While expressing these levels, there are difficulties in understanding the multiplicative terms of binary variables. To overcome these challenges, Chang et al. [139] proposed a revised multi-choice goal programming method. In this method, the multiplicative values of binary variables are not included. This leads to more efficient use and understanding of this method. In the proposed new method, it is also possible to direct the relations between the goals in problems involving multiple goals. At the same time, the goal programming method has been diversified according to in the case of fuzzy and uncertainty. Table 2 lists the studies in which the goal programming method is used in the fuzzy state. Table 3 also shows the use of the goal programming method in uncertain situations.

Table 2. Studies by fuzzy conditions.

\begin{tabular}{lr}
\hline Fuzzy & {$[11,27,29,36,38,42,48,49,67,88,104,111,112,115]$} \\
\hline Non-fuzzy & {$[9,10,12-26,28,30-35,39-41,43-47,50-66,68-87,89-103,105-110,113,114,116-122]$} \\
\hline
\end{tabular}

Table 3. Studies by Uncertainty Status.

\begin{tabular}{lr}
\hline $\begin{array}{l}\text { Stochastic } \\
\text { Chance-Constraint } \\
\text { Stochastic }\end{array}$ & {$[47,93]$} \\
\hline Deterministic & {$[37,84,107]$} \\
\hline
\end{tabular}


Tables 2 and 3 show that there is a limited number of fuzzy and stochastic studies. Uncertainty situations vary according to the problems researchers address. Most researchers are doing solutions under hypotheses in their work. However, even if the number is small, it seems that they are taken into account in their uncertainties.

\subsection{Lexicographic Goal Programming}

In some cases, decision-makers may be faced with prioritizing the solution options to achieve their goals. In other words, in order to optimize mathematical approaches in the problems encountered, it is the status of ranking among the objectives in the model. According to this approach, priority structure is mentioned among the preferences. Each component in the objective function represents the deviation variables of the goals placed at the priority level to which it corresponds. Then, according to these priorities, the model is solved, and the result obtained from each priority is added to run the next priority on the model. This resolution continues until the last priority is executed. This is defined as sequential reduction of each priority. The mathematical formulation of priority goal programming is as follows $[137,140]$ :

$$
\operatorname{LEXMIN}_{a}=\left[\sum_{i \in h_{1}}\left(\alpha_{i} \cdot d_{i}^{-}+\beta_{i} \cdot d_{i}^{+}\right), \ldots, \sum_{i \epsilon h_{r}}\left(\alpha_{i} \cdot d_{i}^{-}+\beta_{i} \cdot d_{i}^{+}\right), \ldots, \sum_{i \epsilon h_{Q}}\left(\alpha_{i} \cdot d_{i}^{-}+\beta_{i} \cdot d_{i}^{+}\right)\right]
$$

subject to

$$
\begin{gathered}
f_{i}(x)+d_{i}^{-}-d_{i}^{+}=b_{i} i \in\{1, \ldots, q\}, i \in h_{r}, r \in\{1, \ldots, Q\} \\
d_{i}^{-}, d_{i}^{+} \geq 0 .
\end{gathered}
$$

The expressions in the given mathematical model, $h_{r}$ represents the cluster index with the goals at the $r$. priority level, $\alpha_{q}$ and $\beta_{q}$ represents the weight factors for the $d_{q}^{+}$and $d_{q}^{-}$deviation values, $f_{s}(x)$ represents the goal constraint. $\alpha_{i}=w_{i} / k_{i}$ if $d_{i}^{-}$is unwanted, otherwise $\alpha_{i}=0$ and $\beta_{i}=w_{i} / k_{i}$ if $d_{i}^{+}$is unwanted, otherwise $\beta_{i}=0$. The parameters $w_{i}$ and $k_{i}$ are the weights reflecting preferential and normalizing purposes attached to the achievement of the $i$ th goal. Each component in the objective function minimizes unwanted deviation variables in the goals placed at the level of priority it corresponds to.

The basic logic in priority goal programming starts with giving priorities to the identified goals. Then the model continues with resolving the goals with each priority one by one. The deviation variables $d_{q}^{+}$and $d_{q}^{-}$in the goal constraints are defined as the difference between the achievement level in reaching the goals set by the decision makers and the actual level. If a goal value is below a desired level, a negative deviation is reached, and a positive deviation occurs if a desired value is reached. Deviation variables cannot have a value less than zero. Any variance that is undesirable to be minimized is given a zero value. In Table 4, there are scheduling, and planning studies made using the lexicographic goal programming method in the literature.

Table 4. Studies in the literature according to lexicographic goal programming and weighted goal programming method.

\begin{tabular}{lr}
\hline Lexicographic goal programming & {$[9,17,21,24,36,42,43,52,60,64,69,93,94,116-118,122]$} \\
\hline Weighted goal programming & {$[10,19,22,35,38,40,56,57,75,77,86,100,108]$} \\
\hline
\end{tabular}

In some problems, the results of the solution are affected by the decisions of the decision makers. When there is an importance level among the objectives, it is necessary to prioritize the objectives. Sungur et al. $[17,24,36]$ have identified priority levels among goals using the lexicographic goal programming method in their work. In lexicographic goal programming, decision-makers may not achieve the desired level of satisfaction at the specified goals. In this point, priority is given to the most important goals and the solution process is going on. Lexicographic goal programming is used when decision-makers cannot achieve relative importance of their goals by weight. 


\subsection{Weighted Goal Programming}

When decision-makers' demands are determined precisely, a certain weight is given to the objectives. In the objective function, this weighted sum of deviations is minimized. The deviation variables of the goals have different relative weight in the objective function. Weighted goal programming also makes an effort to achieve multiple goals at the same time. Weighted goal programming is used for problems that cannot be prioritized among goals and can be measured by weighting goals where all goals are same important. The mathematical formulation of weighted goal programming is as follows $[137,141]$ :

$$
\operatorname{Min}_{z}=\sum_{i}^{k}\left(\alpha_{i} d_{i}^{-}+\beta_{i} d_{i}^{+}\right)
$$

subject to

$$
f_{i}(x)+d_{i}^{-}-d_{i}^{+}=b_{i}, \quad i=1 \ldots Q, \quad x \in C_{s} .
$$

In the weighted goal programming, the basic logic is to minimize the sum of the deviations of each goal weighted relative importance weights. Expressions in the given mathematical model; $f_{i}(x)$ represents a linear function of $x$, the attainment of $b_{i}$ represents the desired goal value, $d_{i}^{-}$, $d_{i}^{+}$represents the deviation values in the negative and positive directions from the goal values, $C_{s}$ represents a set of constraints in linear programming. $\alpha_{i}=w_{i} / k_{i}$ if $d_{i}^{-}$is unwanted, otherwise $\alpha_{i}=0$ and $\beta_{i}=w_{i} / k_{i}$ if $d_{i}^{+}$is unwanted, otherwise $\beta_{i}=0$. The parameters $w_{i}$ and $k_{i}$ are the weights reflecting preferential and normalizing purposes attached to the achievement of the $i$ th goal. For decision makers, the weight of each goal may be different. If a goal value is below a desired level, a negative deviation is reached, and a positive deviation occurs if a desired value is reached. Deviation variables cannot have a value less than zero. Any variance that is undesirable to be minimized is given a zero value. Table 4 contains the scheduling and planning studies using the weighted goal programming method in the literature.

Looking at the studies in Table 4, it appears that decision makers have weighted on the goals in the decision-making process. Since these weights are factors that affect the goals in some studies, various methods are integrated. $[10,19,56-77]$ used weighted goal programming method in their studies. Weighted goal programming, which minimizes the weighted sum of the deviations in the goals, can balance the opposites between goals.

\subsection{Chebyshev Goal Programming}

Weighted goal programming and lexicographic goal programming methods are often preferred by the researchers in the literature. However, Chebyshev Goal Programming method, known as Minmax goal programming, is less common in the literature. Although it is not used very often, it has a theoretically important structure. In the Chebyshev goal programming method, there is a tendency to minimize the maximum deviation between goals, rather than the minimization of the priority of deviations or weighted summation of the deviations. In the model, the goals are shown separately and there is no prioritization among the goals.

In this method, first proposed by the authors of [142] in 1976, the objective function consists only of the distance parameter giving the minimization of the maximum deviation [143]. The mathematical formulation of the Chebyshev goal programming method is as follows [137]:

subject to

$$
\begin{aligned}
\left(\alpha_{i} n_{i}+\beta_{i} p_{i}\right)-D & \leq 0 \\
f_{i}(x)+d_{i}^{-}-d_{i}^{+}=t_{i}, & i \in\{1, \ldots, q\} \\
d_{i}^{+}, d_{i}^{-} \geq 0 \quad x & \in F .
\end{aligned}
$$


In the given mathematical model expressions, $d_{i}^{+}$and $d_{i}^{-}$represents deviations in the positive and negative direction from the $i$ goal. If the positive direction deviation is $d_{i}^{+}$for any value greater than zero and the negative direction deviation takes the value " 0 " for $d_{i}^{-}$, the value of the objective function is greater than the goal value. Similarly, for any value greater than zero in the negative direction deviation is $d_{i}^{-}$, if the deviation variable $d_{i}^{+}$in the positive direction has a value of " 0 ", the objective function value is smaller than the goal value. $t_{i}$ is the target level for the $i$ th goal, $x$ is vector of decision variables, $F$ is feasible set of constraints, $D$ is a maximum deviation. In this goal programming approach, the maximum deviation $D$ is minimized. Therefore, is called Minmax goal programming.

In this method, normalization process is performed because there are different units among the goals. Methods such as percent normalization, Euclidean normalization, total normalization, and Zero-one normalization are recommended for normalization. The first and important difference between the other goal programming methods is the phasing of the maximum discovery. The general effect of this punishment is to provide a balance between the levels of the goals, rather than reducing the sum to the minimum if possible. When considering real-life problems, decision-makers can use it to define needs as balancing in many applications.

\section{Goal Programming According to Integrated Method}

In the goal programming method which allows flexibility in the solution process, the goals are transferred with the model goal constraints. In the model of decision makers, the optimal value of the objective function is sought in the solution allowed by the system and goal constraints. In other words, the desired solution is determined according to the area of the desired goals. In the literature, goal programming method is mostly used alone in scheduling and planning studies. However, in recent years it has been integrated with various methods and started to be used. Traditional goal programming methods use simplex-based optimization techniques in the solution process. As the number of factors to consider in the problem structure increases, the difficulty and complexity of the problem also increase. The work integrated with the heuristic methods in the literature facilitates the solution process of the difficult models that cannot be solved by traditional methods. Table 5 shows the studies integrated with the goal programming in the scheduling and planning studies in the literature.

Table 5. The studies integrated with goal programming.

\begin{tabular}{lr}
\hline Multi-Criteria Decision Making & \\
Analytic Hierarchy Process & {$[10,40,75,77,86,130]$} \\
Analytic Network Process & {$[22,57]$} \\
\hline Heuristic Methods & {$[29]$} \\
Particle Swarm Optimization & {$[111]$} \\
$\quad$ Annealing Simulation & {$[50,130]$} \\
\hline Other Methods & {$[51]$} \\
$\quad$ Data Envelopment Analysis & \\
$\quad$ Benchmarking & \\
\hline Not Integrated & \\
$\quad$ Only Goal Programming & {$[9,11-21,23-28,30-39,41-49,52-56,58-74,76-85,87-110,112-122]$} \\
\hline
\end{tabular}

As can be seen from Table 5, the number of studies related to the methods in which the goal programming method is integrated is very limited. The factors that make the solution process difficult can cause the inclusion of the stochastic functions in the studies. For such complicated situations, researchers can increase the effectiveness of the goal programming method by increasing the variety and application area of the models.

In the literature, the goal programming method is often integrated with multi-criteria decision-making methods so that decision makers can weight their goals. The analytical hierarchy process method seems to be preferred. Decision makers first identify the factors that influence goals. 
Then, comparisons are made according to the hierarchical structure or interactions among these factors. According to these comparisons, factors are weighted. Kırış [10] in the course scheduling, [40] in planning information sources in health systems, Güler et al. [75] in planning anesthesia patients, used the analytic hierarchy process method. Hamurcu et al. [22] in staff scheduling, Bağ et al. [57] nurse scheduling used the analytical network process method.

Shahnazari-Shahrezaei et al. [29] have integrated particle swarm optimization with the goal programming method. They have considered the preferences of the employees of the problem type they deal with, and they have developed an algorithm for the complexity of the problem. The performance of the schedules created with this algorithm has been verified. The performance of the schedule created with this algorithm has been verified. During the studies, the effectiveness of the approaches developed by integrating the goal programming method with different methods is being increased. By evaluating the performance of these integrations and approaches, researchers can create more effective schedules in future work.

The goal programming method integrated with methods such as AHP is the solution to the problems experienced in the ongoing weighting situations. In this section, researchers can be interpreted that the researchers have recently turned towards these integrations. According to this evaluation, it is predicted that such integrations will increase. These integrations are composed of potential study topics for future researchers.

\section{Conclusions}

There are many factors and constraints that decision-makers consider in planning and scheduling study in production and service systems. In line with these constraints and limits, there are many objectives that need to be realized at the same time. Since it is impossible to transfer such real-life problems entirely to modeling, researchers are developing solutions algorithms under various assumptions. Optimization of scheduling and planning studies in these systems is tried to be achieved by multi-criteria programming models that simultaneously satisfy conflicting objectives. Today, service systems that operate with the idea of developing technology and meeting the growing desire of consumers face many limitations. Many approaches are being developed to cope with these limitations. Various studies are being carried out in order to be able to cope with these limiting conditions as well as to achieve the determined aims. The goal programming method, which is a multi-criteria programming model, is an effective tool for solving these complex situations. It offers an optimal solution for problems with two or more aims. At the same time, contradictory goals are also included in the modeling. Due to the complicated structure of the problem, sometimes it is faced to there is no solution in the processes with linear programming methods. The goal programming method is used by decision makers as a tool to help with such problems.

In this study, studies about planning and scheduling studies in service systems are examined. We have been researched studies from the first definition of the goal programming method to the today. Goal programming, scheduling, and planning keywords in Emerald, Science Direct, Jstor, Springer, Taylor and Francis, and Google Scholar databases are scanned while the literature is being searched. The studies examined are listed under various headings according to scheduling types, goal programming types, goal programming with integrated methods. The contributions of these studies to the literature and readers are mentioned. The theoretical structure of the goal programming method is discussed, and technical information is provided to the readers. For researchers, a systematic structure of these studies has been established. This structure makes it easier for readers to focus on the topics they are researching. In addition, the studies listed according to scheduling and planning types help the readers to navigate to which areas. Comprehensible lists have been created with the tables presented in this study and accessibility has been facilitated.

It can be seen from the planning and scheduling studies made by the goal programming method that the researchers have applied in a wide range of fields. However, there are a limited number of applications in these areas. Researchers are trying to achieve many goals at the same time by taking 
advantage of the flexibility of the goal programming method. But as with every method, there is a lack of this method. All limitations and restrictions on real life problems are not reflected in the model. Even though it is an indirect way, there are contradictions between goals and these limitations make solution difficult. For this reason, there are various assumptions in studies. In applications performed with the goal programming method, researchers can be satisfied with the results of the solution as much as possible. However, this satisfaction is not always fully realized. For this reason, researchers can make different researches in order to get desired results by going to different approaches. At the same time, in spite of this diversity in scheduling types, it is possible to make an interpretation that developing technology and application fields may have changed if there are so few studies. So, as technology develops, demands and needs change. For this reason, while some areas of service systems are at the foreground, some areas remain behind. The areas shaped according to these desires and needs, the researchers also directed the same direction.

The goal programming method is a method that can allow flexibility on the objectives in decision problems. At this point, researchers can take a look at the different areas of application taking into account other studies in this study. Researchers can build models that offer solutions to different problems. The basis of these models can be taken from other studies presented as a reference in this study. Based on changing technology, it can adapt these studies to today's problems and extend the performance criteria mentioned here. Thus, it can become a source of research for different studies. In addition, the goal programming method helps researchers to achieve the closest successful outcome as possible to various goals and constraints. It makes it possible for researchers to reach multiple goals that conflict with their preferences.

The goal programming method is presented as an effective method to researchers by prioritizing or weighting among the objectives. However, it is foreseen that there may be some points where this advantageous situation becomes a disadvantage. Researchers may find it difficult to prioritize or weight their intended objectives. At this point, they should establish a decision support system for these purposes. This method, which is one of the most suitable tools for researchers for real life problems, may not provide a solution for some problems in polynomial time. In these challenging situations faced by the researchers, it is recommended to continue by making assumptions. In some cases, the problem sufficiently stretched by deviations can be supported by assumptions. Another difficult situation faced by researchers is that sometimes not all goals are accessible. In this case, the researchers can accept the most satisfactory result. Another alternative for difficult-to-solve problems is the integration of goal programming and meta-heuristic algorithms. Utilizing such advances in the solution phase is a good opportunity to achieve goals of the problem.

The subjects surrounding the determination and sensitivity of the solutions in the goal programming method are one of the other areas that can be developed for researchers. Furthermore, unlike the classical formulation, which is insufficient in the solution processes, researchers have developed various extensions of the goal programming method. It is necessary to test the robustness of the solutions offered by the new formulations developed and to determine how the model result will react in variable and parameter variability.

In the study, theoretical information about the frequently used types of the goal programming method in the literature is given and the basic steps of the modeling structure are mentioned. In the studies examined, decision makers use different types according to their importance levels in the goals they set. Some goals are at a more important level in the problem, while others can stay in the background more than others. In this case, the decision makers either prioritize or weight the objectives. Researchers can use different methods integrated with the goal programming method in their work when they are weighing. When weighting is done, it has generally been seen that multi-criteria decision-making methods are utilized. The factors that are effective on the goals weighted and integrated to the solution with multi-criteria decision-making methods. With the other methods used in the integration, the productivity of the planning and scheduling is improved, and their performance is evaluated. 
Often, in manual planning and schedules, the incentive to use the goal programming method needs to be increased. It is thought that these planning and schedules should be made more systematic. The flexibility and effectiveness of the goal programming method needs to be exploited. In changing areas of application, researchers can use this method to transfer many objectives to the objective function. Thus, they can carry out contradictory purposes together with misconceptions. At the same time, by integrating the goal programming method with different methods, the efficiency can be increased, and the performance of the solution results can be improved. With the quality of the programs made, decision-makers can achieve satisfactory results.

Author Contributions: Ş.G. conceptualized the study, conducted analyses, and contributed to writing the manuscript. T.E. provided overall guidance and expertise in conducting the analysis and was a contributor to writing the manuscript. All authors read and approved the final manuscript.

Funding: This research received no external funding.

Conflicts of Interest: The authors declare that there is no conflict of interest regarding the publication of this paper.

\section{References}

1. Uçakcıoğlu, B. Selection of Investment Projects with Multi-Criteria Decision Making and Goal Programming in the Air Defense Industry. Ph.D. Thesis, Kırıkkale University, Kırıkkale, Turkey, 2017.

2. Pinedo, M. Planning and Scheduling in Manufacturing and Services; Springer: New York, NY, USA, 2005.

3. Tamiz, M.; Jones, D.; El-Darzi, E. A review of goal programming and its applications. Ann. Oper. Res. 1995, 58, 39-53. [CrossRef]

4. Tamiz, M.; Jones, D.; Romero, C. Goal programming for decision making: An overview of the current state-of-the-art. Eur. J. Oper. Res. 1998, 111, 569-581. [CrossRef]

5. Jones, D.F.; Tamiz, M. Goal Programming in the Period 1990-2000, Multiple Criteria Optimization: State of the Art Annotated Bibliographic Surveys; Springer: Berlin, Germany, 2003; pp. 129-170.

6. Azmi, R.; Tamiz, M. A Review of Goal Programming for Portfolio Selection, New Developments in Multiple Objective and Goal Programming; Springer: Berlin, Germany, 2010; pp. 15-33.

7. Colapinto, C.; la Torre, D.; Aouni, B. Goal programming for financial portfolio management: A state-of-the-art review. Oper. Res. 2017, 1-20. [CrossRef]

8. Baker, K.R.; Trietsch, D. Principles of Sequencing and Scheduling; John Wiley \& Sons: Hoboken, NJ, USA, 2013.

9. Badri, M.A.; Davis, D.L.; Davis, D.F.; Hollingsworth, J. A multi-objective course scheduling model: Combining faculty preferences for courses and times. Comput. Oper. Res. 1998, 25, 303-316. [CrossRef]

10. Kırıs, Ş. AHP and multichoice goal programming integration for course planning. Int. Trans. Oper. Res. 2014, 21, 819-833. [CrossRef]

11. Ertuğrul, İ; Öztaş, G.Z. Ders Programı Oluşturulmasında 0-1 Tam Sayılı Bulanık Hedef Programlama Yaklaşımı. Ömer Halisdemir Üniversitesi İktisadi ve İdari Bilimler Fakültesi Dergisi 2016, 9, 159-177.

12. Spronk, J. Interactive Multiple Goal Programming as an Aid for Capital Budgeting and Financial Planning with Multiple Goals, Capital Budgeting under Conditions of Uncertainty; Springer: Berlin, Germany, 1981; pp. 188-212.

13. Cook, W.D. Goal programming and financial planning models for highway rehabilitation. J. Oper. Res. Soc. 1984, 35, 217-223. [CrossRef]

14. Topaloglu, S.; Ozkarahan, I. An implicit goal programming model for the tour scheduling problem considering the employee work preferences. Ann. Oper. Res. 2004, 128, 135-158. [CrossRef]

15. Mathirajan, M.; Ramanathan, R. A (0-1) goal programming model for scheduling the tour of a marketing executive. Eur. J. Oper. Res. 2007, 179, 554-566. [CrossRef]

16. Sungur, B. Development of a mixed integer goal programming model for the tour scheduling problem of a beauty salon. Istanb. Univ. J. Sch. Bus. 2008, 37, 49-64.

17. Sungur, B.; Özgüven, C.; Kariper, Y. Shift scheduling with break windows, ideal break periods, and ideal waiting times. Flex. Serv. Manuf. J. 2017, 29, 203-222. [CrossRef]

18. Özcan, E.C.; Varll, E.; Eren, T. Goal programming approach for shift scheduling problems in hydroelectric power plants. Int. J. Inf. Technol. 2017, 10, 363-370.

19. Eren, T.; Varlı, E. Shift Scheduling Problems and A Case Study. Int. J. Inf. Technol. 2017, 10, 185. 
20. Ciritcioğlu, C.; Akgün, S.; Varlı, E.; Eren, T. Shift Scheduling Problem a Solution Suggestion for Safety Officers in University of Kirıkkale. Int. J. Eng. Res. Dev. 2017, 9, 1-23. [CrossRef]

21. Eren, T.; Ünal, F.M. The Solution of Shift Scheduling Problem by Using Goal Programming. Acad. Platf. J. Eng. Sci. 2016, 4, 28-37.

22. Hamurcu, M.; Ünal, F.; Eren, T. The Solution of Shift Scheduling Problem by Using Analytic Network Process and Goal Programming Method. In Proceedings of the International Conference on Multiple Objective Programming, Tlemcen, Algeria, 13-15 December 2015; pp. 17-19.

23. Anderson, A.; Earle, M. Diet planning in the third world by linear and goal programming. J. Oper. Res. Soc. 1983, 34, 9-16. [CrossRef]

24. Körpeli, S.; Şahin, B.; Eren, T. Menu planning with goal programming: A case study. Kırıkkale Univ. J. Soc. Sci. 2012, 2, 121-142.

25. Charnes, A.; Cooper, W.W.; Niehaus, R.J. A Goal Programming Model for Manpower Planning; Carnegie-Mellon Univ Pittsburgh Pa Management Sciences Research Group: Pittsburgh, PA, USA, 1967.

26. Charnes, A.; Cooper, W.; Niehaus, R.; Sholtz, D. An Extended Goal Programming Model for Manpower Planning; Carnegie-Mellon Univ Pittsburgh Pa Management Sciences Research Group: Pittsburgh, PA, USA, 1968.

27. Shahnazari-Shahrezaei, P.; Tavakkoli-Moghaddam, R.; Kazemipoor, H. Solving a multi-objective multi-skilled manpower scheduling model by a fuzzy goal programming approach. Appl. Math. Model. 2013, 37, 5424-5443. [CrossRef]

28. Bektur, G.; Hasgül, S. Workforce scheduling problem according to seniority levels: An application for a service system. J. Econ. Adm. Sci. 2013, 15, 385-402.

29. Shahnazari-Shahrezaei, P.; Tavakkoli-Moghaddam, R.; Kazemipoor, H. Solving a new fuzzy multi-objective model for a multi-skilled manpower scheduling problem by particle swarm optimization and elite tabu search. Int. J. Adv. Manuf. Technol. 2013, 64, 1517-1540. [CrossRef]

30. Goodman, D.A. A goal programming approach to aggregate planning of production and work force. Manag. Sci. 1974, 20, 1569-1575. [CrossRef]

31. Moro, L.M.; Ramos, A. Goal programming approach to maintenance scheduling of generating units in large scale power systems. IEEE Trans. Power Syst. 1999, 14, 1021-1028. [CrossRef]

32. Orhan, İ.; Kapanoğlu, M.; Karakoç, T.H. Concurrent aircraft routing and maintenance scheduling using goal programming. J. Fac. Eng. Archit. Gazi Univ. 2012, 27, 11-16.

33. Stern, H.I. A goal-programming approach to planning for population balance in a multiregional system. Environ. Plan. A 1974, 6, 431-437. [CrossRef]

34. Taylor, B.W., III; Keown, A.J. Planning urban recreational facilities with integer goal programming. J. Oper. Res. Soc. 1978, 29, 751-758. [CrossRef]

35. Levary, R.R.; Choi, T.S. A linear goal programming model for planning the exports of emerging countries. J. Oper. Res. Soc. 1983, 34, 1057-1067. [CrossRef]

36. Bravo, M.; Gonzalez, I. Applying stochastic goal programming: A case study on water use planning. Eur. J. Oper. Res. 2009, 196, 1123-1129. [CrossRef]

37. Sharma, D.K.; Ghosh, D.; Alade, J.A. A fuzzy goal programming approach for regional rural development planning. Appl. Math. Comput. 2006, 176, 141-149. [CrossRef]

38. Subulan, K.; Taşan, A.S.; Baykasoğlu, A. A fuzzy goal programming model to strategic planning problem of a lead/acid battery closed-loop supply chain. J. Manuf. Syst. 2015, 37, 243-264. [CrossRef]

39. Schroeder, R.G. Resource planning in university management by goal programming. Oper. Res. 1974, 22, 700-710. [CrossRef]

40. Lee, C.; Kwak, N. Information resource planning for a health-care system using an AHP-based goal programming method. J. Oper. Res. Soc. 1999, 50, 1191-1198. [CrossRef]

41. Kim, G.C.; Emery, J. An application of zero-one goal programming in project selection and resource planning-A case study from the Woodward Governor Company. Comput. Oper. Res. 2000, 27, 1389-1408. [CrossRef]

42. Oruç, K.O. Menu planning with fuzzy goal programming. J. Manag. Econ. Res. 2014, 23, 33-51.

43. Kwak, N.; Lee, C. A linear goal programming model for human resource allocation in a health-care organization. J. Med. Syst. 1997, 21, 129-140. [CrossRef] [PubMed]

44. Yang, T.-H.; Wang, R.-T.; Tseng, C.-H. The application of goal programming to the Scheduling problem of the professional baseball league. J. Chin. Inst. Ind. Eng. 2009, 26, 135-146. [CrossRef] 
45. Steuer, R.E. Multiple criterion function goal programming applied to managerial compensation planning. Comput. Oper. Res. 1983, 10, 299-309. [CrossRef]

46. De Wit, C.; van Keulen, H.; Seligman, N.; Spharim, I. Application of interactive multiple goal programming techniques for analysis and planning of regional agricultural development. Agric. Syst. 1988, 26, 211-230. [CrossRef]

47. Wang, Y.; Zhou, Z.; Zhao, S.; Xu, Y.; Chen, R.; Yin, J.; Botterud, A. Chance-Constrained Goal-Programming Based Day ahead Scheduling in Wind Power Integrated System. In Proceedings of the Power and Energy Society General Meeting (PESGM), Boston, MA, USA, 17-21 July 2016; pp. 1-5.

48. Peng, J.; Song, K. Expected Value Goal Programming Model for Fuzzy Scheduling Problem. In Proceedings of the 10th IEEE International Conference on Fuzzy Systems, Melbourne, Australia, 2-5 December 2001; pp. 292-295.

49. Ravi, V.; Reddy, P. Fuzzy linear fractional goal programming applied to refinery operations planning. Fuzzy Sets Syst. 1998, 96, 173-182. [CrossRef]

50. Athanassopoulos, A.D. Goal programming \& data envelopment analysis (GoDEA) for target-based multi-level planning: Allocating central grants to the Greek local authorities. Eur. J. Oper. Res. 1995, 87, 535-550.

51. Cherif, M.S.; Chabchoub, H.; Aouni, B. Integrating customer's preferences in the QFD planning process using a combined benchmarking and imprecise goal programming model. Int. Trans. Oper. Res. 2010, 17, 85-102. [CrossRef]

52. Abdallah, M.; Kapelan, Z. Iterative Extended Lexicographic Goal Programming Method for Fast and Optimal Pump Scheduling in Water Distribution Networks. J. Water Resour. Plan. Manag. 2017, 143, 04017066. [CrossRef]

53. Pang, Q.; Wu, X. Optimization scheduling model of double line Shiplock based on nonlinear goal programming. J. Appl. Res. Technol. 2014, 12, 192-200. [CrossRef]

54. Taylor, B.W., III; Anderson, P.F. Goal programming approach to marketing/production planning. Ind. Mark. Manag. 1979, 8, 136-144. [CrossRef]

55. Ben-Awuah, E.; Askari-Nasab, H.; Awuah-Offei, K. Production Scheduling and Waste Disposal Planning for Oil Sands Mining Using Goal Programming. J. Environ. Inform. 2012, 20, 20-33. [CrossRef]

56. Azaiez, M.N.; al Sharif, S.S. A 0-1 goal programming model for nurse scheduling. Comput. Oper. Res. 2005, 32, 491-507. [CrossRef]

57. Bă̆, N.; Özdemir, N.M.; Eren, T. Solving A 0-1 Goal Programming and ANP Methods with Nurse Scheduling Problem. Int. J. Eng. Res. Dev. 2012, 4, 2-6.

58. Jenal, R.; Ismail, W.R.; Yeun, L.C.; Oughalime, A. A cyclical nurse schedule using goal programming. J. Math. Fundam. Sci. 2011, 43, 151-164. [CrossRef]

59. Wang, S.-P.; Hsieh, Y.-K.; Zhuang, Z.-Y.; Ou, N.-C. Solving an outpatient nurse scheduling problem by binary goal programming. J. Ind. Prod. Eng. 2014, 31, 41-50. [CrossRef]

60. Sundari, V.; Mardiyati, S. Solving Cyclical Nurse Scheduling Problem Using Preemptive Goal Programming. In AIP Conference Proceedings; AIP Publishing: Melville, NY, USA, 2017; p. 030132.

61. Hakim, L.; Bakhtiar, T. The Nurse Scheduling Problem: A Goal Programming and Nonlinear Optimization Approaches. In IOP Conference Series: Materials Science and Engineering; IOP Publishing: Bristol, UK, 2017; p. 012024.

62. Musa, A.; Saxena, U. Scheduling nurses using goal-programming techniques. IIE Trans. 1984, 16, $216-221$. [CrossRef]

63. Huarng, F. A primary shift rotation nurse scheduling using zero-one linear goal programming. Comput. Nurs. 1999, 17, 135-144. [PubMed]

64. Varlı, E.; Ergişi, B.; Eren, T. Nurse scheduling problem with special constraints: Goal programming approach. Erciyes Univ. Fac. Econ. Adm. Sci. J. 2017, 0, 189-206.

65. Ferland, J.A.; Berrada, I.; Nabli, I.; Ahiod, B.; Michelon, P.; Gascon, V.; Gagné, É. Generalized assignment type goal programming problem: Application to nurse scheduling. J. Heuristics 2001, 7, 391-413. [CrossRef]

66. Agyei, W.; Obeng-Denteh, W.; Andaam, E.A. Modeling nurse scheduling problem using 0-1 goal programming: A case study of Tafo Government Hospital, Kumasi-Ghana. Int. J. Sci. Technol. Res. 2015, 4, 5-10.

67. Tamiz, M.; Yaghoobi, M.A. Nurse Scheduling by Fuzzy Goal Programming, New Developments in Multiple Objective and Goal Programming; Springer: Berlin, Germany, 2010; pp. 151-163. 
68. Atmaca, E.; Pehlivan, C.; Aydoğdu, C.B.; Yakıc1, M. Nurse scheduling problem and application. Erciyes Univ. Sci. Inst. J. 2012, 28, 351-358.

69. Eren, T.; Varlı, E.; Aktürk, M.S. The Solutions of Nurse Scheduling Problem of Full-Time Shift and Special Days Off with Goal Programming. Kırıkkale Univ. J. Soc. Sci. 2017, 7, 1-16.

70. Eren, T.; Şahiner, M.; Aktürk, M.S.; Bedir, N.; Ünlüsoy, S. A nursing scheduling for model suggestion: A case study. Trakya Univ. Fac. Econ. Adm. Sci. J. 2017, 6, 62-77.

71. Varlı, E.; Eren, T. Nurse scheduling problems and an application in hospital. APJES 2017, 5, $34-40$.

72. Aktunc, E.A.; Tekin, E. Nurse Scheduling with Shift Preferences in a Surgical Suite Using Goal Programming. In Industrial Engineering in the Industry 4.0 Era; Springer: Berlin, Germany, 2018; pp. 23-36.

73. Ismail, W.R.; Jenal, R.; Hamdan, N.A. Goal programming based master plan for cyclical nurse scheduling. J. Theor. Appl. Inf. Technol. 2012, 46, 499-504.

74. Ozkarahan, I.; Bailey, J.E. Goal programming model subsystem of a flexible nurse scheduling support system. IIE Trans. 1988, 20, 306-316. [CrossRef]

75. Güler, M.G.; İdi, K.; Güler, E.Y. A goal programming model for scheduling residents in an anesthesia and reanimation department. Expert Syst. Appl. 2013, 40, 2117-2126. [CrossRef]

76. Louly, M.A.O. A goal programming model for staff scheduling at a telecommunications center. J. Math. Model. Algorithms Oper. Res. 2013, 12,167-178. [CrossRef]

77. Topaloglu, S. A multi-objective programming model for scheduling emergency medicine residents. Comput. Ind. Eng. 2006, 51, 375-388. [CrossRef]

78. Yaacob, W.F.W.; Jauhari, N.E.; Yaacob, W.F.W. Development of 0-1 goal programming model for bus driver scheduling. AIP Conf. Proc. 2012, 1482, 376-381.

79. Todovic, D.; Makajic-Nikolic, D.; Kostic-Stankovic, M.; Martic, M. Police officer scheduling using goal programming. Polic. Int. J. Police Strateg. Manag. 2015, 38, 295-313. [CrossRef]

80. Özcan, E.; Varlı, E.; Eren, T. Shift Personnel Scheduling in Hydroelectric Power Plants with Goal Programming Approach. J. Inf. Technol. 2017, 10, 363-370.

81. Lin, H.-T.; Chen, Y.-T.; Chou, T.-Y.; Liao, Y.-C. Crew rostering with multiple goals: An empirical study. Comput. Ind. Eng. 2012, 63, 483-493. [CrossRef]

82. Chu, S.C. Generating, scheduling and rostering of shift crew-duties: Applications at the Hong Kong International Airport. Eur. J. Oper. Res. 2007, 177, 1764-1778. [CrossRef]

83. Gordon, L.; Erkut, E. Improving volunteer scheduling for the Edmonton Folk Festival. Interfaces 2004, 34, 367-376. [CrossRef]

84. Easton, F.F.; Rossin, D.F. A stochastic goal program for employee scheduling. Decis. Sci. 1996, 27, 541-568. [CrossRef]

85. Min, H. A disaggregate zero-one goal programming model for the flexible staff scheduling problem. Soc. Econ. Plan. Sci. 1987, 21, 271-282. [CrossRef]

86. Bedir, N.; Eren, T.; Dizdar, E.N. Ergonomic staff scheduling and an application in the retail sector. Eng. Sci. Des. J. 2017, 5, 657-674.

87. Eren, T.; Özder, E.H.; Varlı, E. A Model Suggestion for Cleaning Staff Scheduling Problem with Goal Programming Approach. Black Sea J. Sci. 2017, 7, 114-127.

88. Kağnıcıŏlu, C.H.; Yıldız, A. Solution to job assignment problem by a 0-1 integer fuzzy goal programming approach. Anadolu Univ. Sci. Technol. J. 2006, 7, 413-429.

89. Varlı, E.; Alağaş, H.; Eren, T.; Özder, E.H. Goal Programming Solution of the Examiner Assignment Problem. Bilge Int. J. Sci. Technol. Res. 2017, 1, 105-118.

90. Charnes, A.; Cooper, W.W.; Learner, D.B.; Snow, E.F. Note on an application of a goal programming model for media planning. Manag. Sci. 1986, 14, B-431-B-436. [CrossRef]

91. Kluyver, C.A. An exploration of various goal programming formulations-With application to advertising media scheduling. J. Oper. Res. Soc. 1979, 30, 167-171.

92. Charnes, A.; Cooper, W.W.; DeVoe, J.; Learner, D.B.; Reinecke, W. A goal programming model for media planning. Manag. Sci. 1968, 14, B-423-B-430. [CrossRef]

93. Bhattacharya, U. A chance constraints goal programming model for the advertising planning problem. Eur. J. Oper. Res. 2009, 192, 382-395. [CrossRef]

94. Ortuño, M.T.; Vitoriano, B. A goal programming approach for farm planning with resources dimensionality. Ann. Oper. Res. 2011, 190, 181-199. [CrossRef] 
95. Wheeler, B.; Russell, J. Goal programming and agricultural planning. J. Oper. Res. Soc. 1977, $28,21-32$. [CrossRef]

96. Romero, C.; Rehman, T. Goal programming and multiple criteria decision-making in farm planning: Some extensions. J. Agric. Econ. 1985, 36, 171-185. [CrossRef]

97. Da Silva, A.F.; Marins, F.A.S.; Dias, E.X. Addressing uncertainty in sugarcane harvest planning through a revised multi-choice goal programming model. Appl. Math. Model. 2015, 39, 5540-5558. [CrossRef]

98. Zengin, H.; Asan, Ü.; Destan, S.; Engin Ünal, M.U.; Yeşil, A.; Bettinger, P.; Değermenci, A.S. Modeling harvest scheduling in multifunctional planning of forests for longterm water yield optimization. Nat. Resour. Model. 2015, 28, 59-85. [CrossRef]

99. Field, R.C.; Dress, P.E.; Fortson, J.C. Complementary linear and goal programming procedures for timber harvest scheduling. For. Sci. 1980, 26, 121-133.

100. Kao, C.; Brodie, J.D. Goal programming for reconciling economic, even-flow, and regulation objectives in forest harvest scheduling. Can. J. For. Res. 1979, 9, 525-531. [CrossRef]

101. Hof, J.G.; Pickens, J.B.; Bartlett, E. A MAXMIN approach to nondeclining yield timber harvest scheduling problems. For. Sci. 1986, 32, 653-666.

102. Cornett, D.; Williams, W.A. Goal programming for multiple land use planning at Mineral King, California. J. Soil Water Conserv. 1991, 46, 373-376.

103. El-Shishiny, H. A goal programming model for planning the development of newly reclaimed lands. Agric. Syst. 1988, 26, 245-261. [CrossRef]

104. Biswas, A.; Pal, B.B. Application of fuzzy goal programming technique to land use planning in agricultural system. Omega 2005, 33, 391-398. [CrossRef]

105. Arp, P.A.; Lavigne, D.R. Planning with goal programming: A case study for multiple-use of forested land. For. Chron. 1982, 58, 225-232. [CrossRef]

106. Gómez, T.; Hernández, M.; León, M.; Caballero, R. A forest planning problem solved via a linear fractional goal programming model. For. Ecol. Manag. 2006, 227, 79-88. [CrossRef]

107. Eyvindson, K.; Kangas, A. Stochastic goal programming in forest planning. Can. J. For. Res. 2014, 44, 1274-1280. [CrossRef]

108. Hotvedt, J.E. Application of linear goal programming to forest harvest scheduling. J. Agric. Appl. Econ. 1983, 15, 103-108. [CrossRef]

109. Prakash, J.; Sinha, S.; Sahay, S. Bus transportation crews planning by goal programming. Soc. Econ. Plan. Sci. 1984, 18, 207-210. [CrossRef]

110. Strang, K.D. Logistic planning with nonlinear goal programming models in spreadsheets. Int. J. Appl. Logist. (IJAL) 2012, 3, 1-14. [CrossRef]

111. Mokhtari, H.; Hasani, A. A multi-objective model for cleaner production-transportation planning in manufacturing plants via fuzzy goal programming. J. Manuf. Syst. 2017, 44, 230-242. [CrossRef]

112. Liang, T.-F. Applying fuzzy goal programming to production/transportation planning decisions in a supply chain. Int. J. Syst. Sci. 2007, 38, 293-304. [CrossRef]

113. Yaghini, M.; Alimohammadian, A.; Sharifi, S. A goal programming technique for railroad passenger scheduling. Manag. Sci. Lett. 2002, 2, 535-542. [CrossRef]

114. Ben-Awuah, E.; Askari-Nasab, H. Oil sands mine planning and waste management using mixed integer goal programming. Int. J. Min. Reclam. Environ. 2011, 25, 226-247. [CrossRef]

115. Chang, N.-B.; Wang, S. A fuzzy goal programming approach for the optimal planning of metropolitan solid waste management systems. Eur. J. Oper. Res. 1997, 99, 303-321. [CrossRef]

116. Cappanera, P.; Visintin, F.; Banditori, C. A Goal-Programming Approach to the Master Surgical Scheduling Problem. In Health Care Systems Engineering for Scientists and Practitioners; Springer: Berlin, Germany 2016; pp. $155-166$.

117. Cappanera, P.; Visintin, F.; Banditori, C. Addressing conflicting stakeholders' priorities in surgical scheduling by goal programming. Flex. Serv. Manuf. J. 2018, 30, 252-271. [CrossRef]

118. Ozkarahan, I. Allocation of surgeries to operating rooms by goal programing. J. Med. Syst. 2000, 24, 339-378. [CrossRef] [PubMed]

119. Ogulata, S.N.; Erol, R. A hierarchical multiple criteria mathematical programming approach for scheduling general surgery operations in large hospitals. J. Med. Syst. 2003, 27, 259-270. [CrossRef] [PubMed] 
120. Arenas, M.; Bilbao, A.; Caballero, R.; Gómez, T.; Rodriguez, M.; Ruiz, F. Analysis via goal programming of the minimum achievable stay in surgical waiting lists. J. Oper. Res. Soc. 2002, 53, 387-396. [CrossRef]

121. Rifai, A.K.; Pecenka, J.O. An application of goal programming in healthcare planning. Int. J. Oper. Prod. Manag. 1990, 10, 28-37. [CrossRef]

122. Güler, M.G. A hierarchical goal programming model for scheduling the outpatient clinics. Expert Syst. Appl. 2013, 40, 4906-4914. [CrossRef]

123. Amiri, S.; Honarvar, M.; Sadegheih, A. Providing an integrated Model for Planning and Scheduling Energy Hubs and preventive maintenance. Energy 2018, 163, 1093-1114. [CrossRef]

124. Hemmati, R.; Saboori, H.; Jirdehi, M.A. Stochastic planning and scheduling of energy storage systems for congestion management in electric power systems including renewable energy resources. Energy 2017, 133, 380-387. [CrossRef]

125. Koltsaklis, N.E.; Giannakakis, M.; Georgiadis, M.C. Optimal energy planning and scheduling of microgrids. Chem. Eng. Res. Des. 2018, 131, 318-332. [CrossRef]

126. Liu, Y.; Yu, S.; Zhu, Y.; Wang, D.; Liu, J. Modeling, planning, application and management of energy systems for isolated areas: A review. Renew. Sustain. Energy Rev. 2018, 82, 460-470. [CrossRef]

127. Ma, T.; Wu, J.; Hao, L.; Lee, W.-J.; Yan, H.; Li, D. The optimal structure planning and energy management strategies of smart multi energy systems. Energy 2018, 160, 122-141. [CrossRef]

128. Deshmukh, S.S.; Deshmukh, M.K. A new approach to micro-level energy planning-A case of northern parts of Rajasthan, India. Renew. Sustain. Energy Rev. 2009, 13, 634-642. [CrossRef]

129. Jinturkar, A.M.; Deshmukh, S.S. A fuzzy mixed integer goal programming approach for cooking and heating energy planning in rural India. Expert Syst. Appl. 2011, 38, 11377-11381. [CrossRef]

130. Özcan, E.C.; Ünlüsoy, S.; Eren, T. A combined goal programming-AHP approach supported with TOPSIS for maintenance strategy selection in hydroelectric power plants. Renew. Sustain. Energy Rev. 2017, 78, 1410-1423. [CrossRef]

131. Charnes, A.; Cooper, W.W.; Ferguson, R.O. Optimal estimation of executive compensation by linear programming. Manag. Sci. 1955, 1, 138-151. [CrossRef]

132. Charnes, A.; Cooper, W. Management Models and Industrial Applications of Linear Programming; John Wiley and Sons: New York, NY, USA, 1961.

133. Türkoğlu, S.P. Goal programming method and applications in decision making. Osmaniye Korkut Ata Univ. J. Econ. Adm. Sci. 2017, 1, 29-46.

134. Jones, D.F.; Wall, G. An extended goal programming model for site selection in the offshore wind farm sector. Ann. Oper. Res. 2016, 245, 121-135. [CrossRef]

135. Romero, C. Extended lexicographic goal programming: A unifying approach. Omega 2001, $29,63-71$. [CrossRef]

136. Vitoriano, B.; Romero, C. Extended interval goal programming. J. Oper. Res. Soc. 1999, 50, $1280-1283$. [CrossRef]

137. Romero, C. A general structure of achievement function for a goal programming model. Eur. J. Oper. Res. 2004, 153, 675-686. [CrossRef]

138. Chang, C.T. Multi-choice goal programming. Omega 2007, 35, 389-396. [CrossRef]

139. Chang, C.T. Revised multi-choice goal programming. Appl. Math. Model. 2008, 32, 2587-2595. [CrossRef]

140. Lee, S.M. Goal Programming for Decision Analysis; Auerbach Publishers: Philadelphia, PA, USA, 1972.

141. Romero, C. Handbook of Critical Issues in Goal Programming; Elsevier: Amsterdam, Netherlands, 2014.

142. Flavell, R. A new goal programming formulation. Omega 1976, 4, 731-732. [CrossRef]

143. Güngör, M.; Umarusman, N.; Güneş, M. Use of goal programming and fuzzy goal programming under capital constraints in best price determination processes and an application. In Proceedings of the 31st National Operations Research and Industrial Engineering Congress, Sakarya, Turkey, 8-9 January 2011; pp. 1-9.

(C) 2018 by the authors. Licensee MDPI, Basel, Switzerland. This article is an open access article distributed under the terms and conditions of the Creative Commons Attribution (CC BY) license (http:/ / creativecommons.org/licenses/by/4.0/). 